\title{
Improving Reading Comprehension Skills Through Powerpoint Flashcard Media in Class III SD 4 Menawan
}

\author{
Muhammad Dzulkirom \\ Universitas Sebelas Maret \\ dzoel.kirom@gmail.com
}

\section{Article History}

received 30/4/2021

revised 30/5/2021

accepted 30/6/2021

\begin{abstract}
This research aim to improve reading comprehension skills by apply flashcard and powerpoint media. This research is a classroom action research (CAR) with two cycles. The subjects of this study were $3^{\text {rd }}$ grade students of SD 4 Menawan Gebog Kudus, totaling 12 students. Data collection was done by observation, test and documentation techniques. Data validity uses content validity techniques. Data analysis uses the Milles and Huberman interactive analysis model. From the results of the pre-action activities, only 2 out of $12(16,67 \%)$ students completed. In the implementation of the first cycle there was an increase, 6 out of $12(50 \%)$ students completed. Then in the second cycle showed a large increase, namely 11 out of 12 $(91,67 \%)$ students completed. Thus, it can be concluded that the use of powerpoint flashcard media can improve the reading comprehension skills of $3^{\text {rd }}$ graders at SD 4 Menawan Gebog Kudus.
\end{abstract}

Keywords: Reading Comprehension Skills, Flashcard, Powerpoint

\begin{abstract}
Abstrak
Penelitian ini bertujuan untuk meningkatkan keterampilan membaca pemahaman dengan menerapkan media flashcard dan powerpoint. Penelitian ini merupakan penelitian tindakan kelas (PTK) dengan dua siklus. Subjek penelitian ini adalah peserta didik kelas III SD 4 Menawan Gebog Kudus yang berjumlah 12 peserta didik. Pengumpulan data dilakukan dengan teknik observasi, tes, dan dokumentasi. Validitas data menggunakan teknik validitas isi. Analisis data menggunakan model analisis interaktif Milles dan Huberman. Dari hasil kegiatan pratindakan menunjukkan hanya 2 dari $12(16,67 \%)$ peserta didik yang tuntas. Pada pelaksanaan siklus I terjadi peningkatan, 6 dari $12(50 \%)$ peserta didik tuntas. Kemudian pada siklus II menunjukkan peningkatan yang besar, yaitu 11 dari 12 (91,67\%) peserta didik tuntas. Dengan demikian dapat disimpulkan bahwa penggunaan media flashcard powerpoint dapat meningkatkan keterampilan membaca pemahaman peserta didik kelas III SD 4 Menawan Gebog Kudus.
\end{abstract}

Kata kunci: Keterampilan Membaca Pemahaman, Flashcard, Powerpoint 


\section{PENDAHULUAN}

Penyelenggaraan pendidikan di Indonesia berdasarkan Peraturan Menteri Pendidikan dan Kebudayaan Nomor 57 Tahun 2014 mempunyai tujuan mempersiapkan manusia Indonesia agar memiliki kemampuan hidup sebagai pribadi dan warga negara yang beriman, produktif, kreatif, inovatif, dan afektif serta mampu berkontribusi pada kehidupan bermasyarakat, berbangsa, bernegara, dan peradaban dunia.

Bahasa Indonesia merupakan salah satu muatan pelajaran pokok yang ada dalam kurikulum pendidikan di Indonesia salah satunya di satuan sekolah dasar yang harus diwujudkan atau dilaksanakan sesuai dengan tujuan pendidikan nasional di Indonesia. Bahasa Indonesia di sekolah dasar merupakan konsep terpadu. Pembelajaran Bahasa Indonesia membuka kesempatan kepada peserta didik untuk memupuk kreatifitas dalam konteks lisan maupun tulisan.

Menurut Susanto (2016: 242-243) menyatakan bahwa pembelajaran bahasa Indonesia, terutama si sekolah dasar tidak akan terlepas dari empat keterampilan berbahasa, yaitu menyimak, berbicara, membaca, dan menulis. Keempaat keterampilan bahasa tersebut dalam penggunaanya sebagai alat komunikasi tidak pernah dapat berdiri sendiri karena saling berkaitan. Namun, pada umunya peserta didik sukar untuk menentukaninformasi dari bacaan, dikarenakan pada saat usia tersebut baru saja memasuki tahap analisis apa yang dibaca ataupun disimaknya.

Pendidikan dan media pembelajaran merupakan dua hal yang saling berkaitan, dimana suatu pembelajaran tidak akan berjalan lancar apabila media yang digunakan tidak sesuai atau tidak tepat. Menurut Rayandra Asyhar (2012: 8) media pembelajaran merupakan segala sesuatu yang dapat menyampaikan atau menyaluran pesan dari suatu sumber secara terencana sehingga terjadi lingkungan belajar yang kondusif dimana penerimanya dapat melakukan proses belajar secara efisien dan efektif. Media ini berfungsi sebagai alat bantu guru untuk menyalurkan pesan atau materi pembelajaran kepada peserta didik. Pemanfaatan media ini dimaksudkan untuk merangsang perasaan, pikiran, dan minat peserta didik untuk menciptakan pembelajaran yang menarik dan menyenangkan.

Masa pandemi covid-19 mengubah tatanan kehidupan terutama pada kegiatan belajar mengajar. Sebelum masa pandemi covid-19 kegiatan pembelajaran yang dilaksanakan secara tatap muka di sekolah harus dihentikan dengan mengganti pelaksanaan pembelajaran secara daring dan luring. Perubahan pelaksanaan pembelajaran yang mendadak ini membuat guru dan peserta didik harus bisa menyesuaikan dengan sistem pembelajaran yang baru meski masih ada keterbatasan untuk melaksanakan pembelajaran daring dan luring.

Dampak dari pembelajaran daring dan luring yang mendadak ini terlihat dari kegiatan pembelajaran secara daring yang dilaksanakan sebagai syarat terpenuhinya kegiatan pembelajaran tanpa memperhatikan proses dan hasil belajar. Selama pembelajaran daring dan luring banyak guru yang kurang mempersiapkan materi bahan ajar atau media pembelajaran sehingga kebanyakan pembelajaran daring hanya melakukan penjelasan tugas dan pemberian tugas dari buku siswa. Kurangnya materi bahan ajar dan tidak adanya media sebagai alat bantu untuk memahami materi membuat siswa mengerjakan tugas yang diberikan hanya berdasarkan pengetahuannya dari buku siswa saja.

Berdasarkan data dokumentasi hasil belajar nilai harian di SD Menawan Kelas III tema 3 subtema 3 menunjukkan masih banyak peserta didik yang nilai Bahasa Indonesia cenderung rendah dibandingkan dengan muatan pembelajaran yang lainnya. Setelah dilakukan pengumpulan data ditemukan beberapa permasalahan yang terkait dengan pembelajaran bahasa Indonesia. Salah satunya yaitu tentang keterampilan menetukan isi teks lisan, tulisan dan visual sebuah cerita atau informasi. Dengan melihat hasil nilai rata-rata peserta didik kelas III pada Gugus Kenanga 
dengan presentase PPKN ( 80.42 ), Bahasa Indonesia (76.49), Matematika (77.47), SBdP (80.1).

Alternatif yang bisa dilakukan untuk meningkatkan hasil belajar muatan pelajaran Bahasa Indonesia dalam meningkatkan keterampilan membaca pemahaman untuk menemukan isi atau informasi dalam teks lisan, tulis, dan visual adalah dengan menggunakan media flashcard powerpoint. Penggunaan media pembelajaran ini bermaksud untuk meningkatkan keterampilan peserta didik memahami isi dan pesan teks bacaan. Peneliti memilih menggunakan media flashcard powerpoint karena media akan lebih menarik bagi peserta didik sehingga bisa memotivasi untuk belajar dan lebih mudah menemukan informasi. Sesuai dengan pendapat Indriana (2011: 69) bahwa flashcard mudah diingat karena flashcard bergambar menarik perhatian, sehingga merangsang otak untuk lebih lama mengingat pesan dalam flashcard.

Penelitian yang mendukung penelitian ini adalah penelitian dari Nirmawati dan Tarman Andi Arief tahun 2018 dengan judul "Pengaruh Penggunaan Media Pembelajaran PowerPoint Terhadap Minat Dan Kemampuan Membaca Siswa Pada Mata Pelajaran Bahasa Indonesia Kelas IV. Hasil penelitian dari Nirmawati dan Tarman Andi Arief menyimpulkan bahwa penggunaan media pembelajaran PowerPoint berpengaruh terhadap minat dan kemampuan membaca siswa kelas IV SDN 03 Ele Kabupaten Barru.

Berdasarkan latar belakang yang telah diuraikan diatas maka peneliti membuat inovasi dalam membuat media pembelajaran yang bisa membantu peserta didik untuk bisa meningkatkan keterampilan membaca pemahaman. Dari gagasan tersebut peneliti melakukan penelitian tindakan kelas yang bertujuan untuk: (1) Mendeskripsikan peningkatan aktivitas peserta didik kelas III SD 4 Menawan Kecamatan Gebog Kabupaten Kudus pada keterampilan membaca pemahaman menggunakan media flashcard powerpoint.dan (2) Mendeskripsikan peningkatan keterampilan membaca pemahaman pada peserta didik kelas 3 SD 4 Menawan Kecamatan Gebog Kabupaten Kudus menggunakan media flashcard powerpoint.

\section{METODE}

Penelitian ini menggunakan pendekatan kualitatif dengan jenis penelitian yang digunakan adalah penelitian tindakan kelas. Penelitian Tindakan Kelas ditandai dengan adanya tindakan. Satu tindakan terdiri dari rangkaian 4 kegiatan. Satu tindakan tersebut disebut sebagai satu siklus yang terdiri dari perencanaan, pelaksanaan, observasi, dan refleksi. (Suhardjono dalam Arikunto, 2015:153).

Subjek dalam penelitian ini adalah peserta didik kelas III SD 4 Menawan semester 2 Tahun Pelajaran 2020/ 2021 dengan jumlah peserta didik 12 anak yang terdiri 5 peserta didik laki-laki dan 7 peserta didik perempuan dengan satu rombongan belajar. Data kualitatif dalam penelitian ini adalah data aktifitas peserta didik pada pembelajaran dalam penerapan media flashcard powerpoint sesuai dengan kriteria yang terdapat pada lembar observasi. Data kuantitatif berupa hasil belajar peserta didik setelah menerapkan media flashcard powerpoint. Sumber data primer diperoleh dari guru dan peserta didik kelas III SD 4 Menawan tahun ajaran 2020/2021. Sumber data sekunder berupa silabus, RPP, dan dokumentasi saat pembelajaran. Teknik pengumpulan data menggunakan tes, observasi, dan dokumentasi. Teknik analisis data yang digunakan oleh peneliti yakni teknik deskriptif komparatif dan analisis data interaktif yang dikembangkan oleh Miles dan Huberman yang terdiri dari data collection, data reduction, data display, dan data conclusing drawing atau verification. (Sugiyono, $2015: 247-252$ )

\section{HASIL DAN PEMBAHASAN}

Indikator kinerja pada penelitian ini yakni terjadinya peningkatan keterampilan membaca pemahaman pada peserta didik kelas III SD 4 Menawan setelah diterapkan 
pembelajaran dengan media flashcard powerpoint sebesar $80 \%$ peserta didik memeperoleh nilai keterampilan $\geq 70$. Penelitian dilaksanakan dengan menerapkan tindakan prasiklus terlebih dahulu untuk mengukur keterampilan membaca pemahaman peserta didik. Berdasarkan hasil tes pratindakan, diperoleh data bahwa keterampilan membaca pemahaman peserta didik masih rendah.

Tabel 1. Tabel Sekor Keterampilan Membaca Pemahaman Pratindakan

\begin{tabular}{|c|c|c|c|c|c|}
\hline No & Kategori & Interval & Frekuensi & Presentase & Ketuntasan \\
\hline 1 & Tidak terampil & $4-6,4$ & 0 & $0 \%$ & Tidak tuntas \\
\hline 2 & Kurang terampil & $6,5-8,8$ & 5 & $42 \%$ & Tidak tuntas \\
\hline 3 & Cukup terampil & $8,9-11,2$ & 5 & $42 \%$ & Tidak tuntas \\
\hline 4 & Terampil & $11,3-13,6$ & 2 & $17 \%$ & Tuntas \\
\hline 5 & Sangat terampil & $13,7-16$ & 0 & $0 \%$ & Tuntas \\
\hline & ata-rata sekor & \multicolumn{4}{|c|}{9,3} \\
\hline & Sekor tertinggi & \multicolumn{4}{|c|}{12} \\
\hline & ekor terendah & \multicolumn{4}{|c|}{7} \\
\hline & ta-rata klasikal & \multicolumn{4}{|c|}{12} \\
\hline & untasan klasikal & \multicolumn{4}{|c|}{$16,67 \%$} \\
\hline
\end{tabular}

Tabel 2 menunjukkan presentase peserta didik yang tuntas yaitu 17\% sedangkan $93 \%$ peserta didik belum memenuhi ketuntasan. Meskipun sebanyak $42 \%$ peserta didik dalam kategori cukup terampil akan tetapi belum memenuhi ketuntasan minimal.

Pelaksanaan tindakan dilaksanakan sebanyak dua siklus. Terdapat peningkatan pada aktivitas peserta didik dan peningkatan keterampilan membaca pemahaman.

Tabel 2. Perbandingan Hasil Aktivitas Peserta Didik Siklus I dan Siklus II.

\begin{tabular}{ccccc}
\hline No & $\begin{array}{c}\text { Aktivitas Peserta } \\
\text { Didik }\end{array}$ & $\begin{array}{c}\text { Jumlah } \\
\text { Skor }\end{array}$ & $\begin{array}{c}\text { Rerata } \\
\text { Skor }\end{array}$ & Kategori \\
\hline 1 & Siklus I & 14 & 2,8 & Baik \\
2 & Siklus II & 17 & 3,4 & Sangat Baik \\
\hline
\end{tabular}

Berdasarkan Tabel 2 dapat dilihat aktivitas peserta didik dari siklus pertama hingga kedua mengalami peningkatan. Siklus pertama rerata skor aktivitas peserta didik adalah 2,8 yang termasuk dalam kategori baik. Siklus kedua mengalami kenaikan rerata sebesar 0,6 dari menjadi 3,4. Rerata tersebut termasuk dalam kategori sangat baik. Aktivitas peserta didik selama tindakan siklus I sampai dengan siklus II mengalami peningkatan.

Keterampilan membaca pemahaman peserta didik juga mengalami peningkatan. Perbandingan hasil keterampilan membaca pemahaman peserta didik antarsiklus disajikan dalam tabel dan grafik di bawah ini.

Tabel 3. Perbandingan Hasil Nilai Keterampilan Membaca Pemahaman Antarsiklus

\begin{tabular}{ccccc}
\hline No & Keterangan & Pratindakan & Siklus I & Siklus II \\
\hline 1 & Skor tertinggi & 12 & 14 & 15 \\
2 & Skor terendah & 7 & 9 & 11 \\
3 & Rata-rata klasikal & 12 & 12,8 & 13,4 \\
4 & Ketuntasan klasikal & $16,67 \%$ & $50,00 \%$ & $91,67 \%$ \\
\hline
\end{tabular}




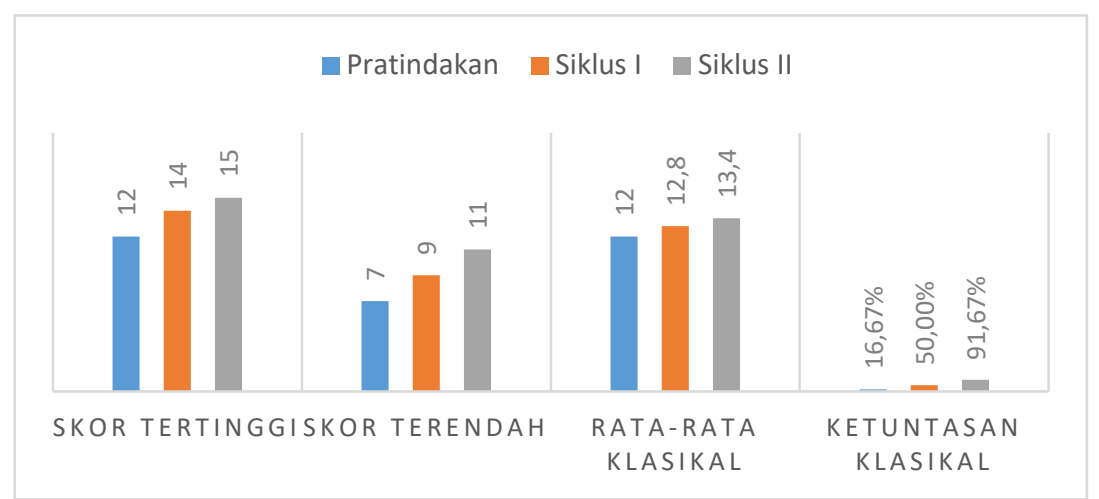

\section{Gambar 1. Diagram Perbandingan Hasil Nilai Keterampilan Membaca Pemahaman}

Tabel 4 dan Gambar 1 di atas menunjukkan bahwa keterampilan membaca pemahaman peserta didik pada tiap siklus mengalami peningkatan yang siknifikan. Skor tertinggi pada pratindakan adalah 12. Pada siklus I skor tertinggi meningkat menjadi 14. Peningkatan skor tertinggi juga terjadi pada siklus II yaitu 15 . Skor terendah peserta didik pada pratindakan adalah 7 , selanjutnya pada siklus I skor terendah terjadi peningkatan yaitu menjadi 9 dan siklus II meningkat menjadi 11. Ratarata ketuntasan klasikal keterampilan membaca peserta didik pada pratindakan masih rendah yaitu 12 (75). Siklus I terjadi kenaikan pada rata-rata skor klasikal yaitu 12,8 (80) dan pada siklus II rata-rata skor klasikal meningkat menjadi 13,4 (83). Persentase ketuntasan klasikal juga mengalami peningkatan. Pada pratindakan persentase ketuntasan klasikal sebesar $16,67 \%$, kemudian meningkat pada siklus I sebesar $50 \%$. Peningkatan juga terjadi pada siklus II yaitu sebesar 91,67\%. Data tersebut telah menunjukkan hasil keterampilan membaca pemahaman peserta didik telah mencapai indikator kinerja penelitian, yaitu $80 \%$ peserta didik telah memperoleh nilai $\geq 70$.

Setelah menerapkan media flashcard powerpoint dalam pembelajaran, perhatian peserta didik dan keterampilan membaca pemahaman dapat meningkatkan. Media yang dikembangkan membuat isi dan informasi bacaan yang disajikan dalam flashcard lebih bermakan sehingga peserta didik lebih mudah mengingat apa yang yang telah ditemukan. Sesuai dengan pendapat Indriana (2011: 69) bahwa flashcard mudah diingat karena menarik perhatian, sehingga merangsang otak untuk lebih lama mengingat pesan dalam flash card.

Peningkatan keterampilan membaca pemahaman yang diperoleh peneliti relevan dengan penelitian yang dilakukan oleh Lestari (2020) tentang peningkatan keterampilan membaca pemahaman dengan media flashcard. Hasil penelitian tersebut menunjukkan adanya peningkatan keterampilan membaca pemahaman peserta didik dari tahap pratindakan hingga setelah penerapan media.

Penelitian yang dilaksanakan peneliti dilakukan selama kondisi pandemi covid19, sehingga proses kegiatan pembelajaran yang dilaksanakan masih terbatas. Pelaksanaan pembelajaran dilaksanakan dengan penerapan protokol kesehatan dengan pembatasan kegiatan pembelajaran yang dilaksanakan maksimal selama 2 jam. Dengan pembatasan tersebut, peneliti berusaha untuk merancang kegiatan pembelajaran lebih efisien yaitu dengan membuat diskusi kelompok pada kegiatan penerapan media flashcard.

Kendala lain yang peneliti alami yaitu pada rencana pelaksanaan siklus III. Untuk membuktikan keakuratan ketercapaian kinerja, peneliti mencoba untuk melanjutkan pada siklus III namun terdapat kendala pada perizinan melaksanakan pembelajaran secara tatap muka dikarenakan peningkatan kasus covid-19 di lingkungan Kabupaten Kudus. Berdasarkan data tindakan pada siklus II menunjukkan indikator ketercapaian 
kinerja sudah terpenuhi sehingga peneliti mengambil sikap menghentikan penelitian di siklus II.

Berdasarkan uraian tersebut, setelah diterapkannya media flashcard powerpoint dalam pembelejaran keterampilan membaca pemahaman peserta didik kelas III SD 4 Menawan mengalami peningkatan. Hasil penelitian ini didukung oleh penelitian yang dilakukan Mei Siska (2020) penelitian menunjukkan penerapan media PowerPoint bernarasi dapat meningkatan hasil belajar bahasa Indonesia. Penelitian lainnya oleh Lestari (2020) menunjukkan adanya peningkatan keterampilan membaca pemahaman peserta didik dari tahap pratindakan hingga setelah penerapan media flashcard.

\section{SIMPULAN}

Berdasarkan hasil penelitian dan pembahasan maka dapat diambil kesimpulan sebagai berikut: (1) Dari hasil kondisi awal pratindakan, siklus I, dan siklus II menunjukkan peningkatan aktifitas peserta didik dengan diterapkannnya media flashcard powerpoint. Perolehan skor rata-rata aktifitas peserta didik siklus I adalah 2,8 dengan presentase $70 \%$ menunjukkan kategori baik. Pada siklus II perolehan skor rata-rata aktifitas peserta didik mencapai 3,4 dengan presentase $85 \%$ menunjukkan kategori sangat baik. (2) Penerapan media flashcard powerpoint pada pelaksanaan tindakan siklus I dan II dapat meningkatkan keterampilan membaca pemahaman peserta didik. Dari hasil kegiatan pratindakan menunjukkan 2 dari 12 peserta didik atau $16,67 \%$ yang tuntas. Pada pelaksanaan siklus I terjadi peningkatan, 6 dari 12 peserta didik atau $50 \%$ yang tuntas. Kemudian pada siklus II menunjukkan peningkatan yang besar, yaitu 11 dari 12 peserta didik atau 91,67\% tuntas. (3) Implikasi dari hasil penelitian tentang peningkatan keterampilan membaca pemahaman dengan penggunaan media pembelajaran flashcard powerpoint dapat menambah pengetahuan pembaca dan dapat menjadi referensi untuk penelitian selanjutnya.

\section{DAFTAR PUSTAKA}

Arikunto, S., dkk. (2012). Penelitian Tindakan Kelas. Jakarta: Bumi Aksara.

Asyhar, R. (2012). Kreatif Mengembangkan Media Pembelajaran. Jambi: Referensi. Indriana, D. (2011). Ragam Alat Bantu Media Pengajaran. Yogjakarta: DIVA. Press.

Kementrian Pendidikan dan Kebudayaan RI. (2011). Peraturan Mendiknas tentang Tentang Kurikulum 2013 SD/MI (Permendiknas Nomor 57 tahun 2014). Jakarta: Penulis.

Lestari, W.E. (2020). Penggunaan Media Flashcard untuk Meningkatkan Keterampilan Membaca Pemahaman Peserta Didik Kelas III Sekolah Dasar. Jurnal IImiah Pendidikan (6)1 70-75. Diperoleh dari https://jurnal.uns.ac.id/jpi/article/view/ 40513

Nirmawati. \& Arief, T. (2018). Pengaruh Penggunaan Media Pembelajaran Power Point terhadap Minat dan Kemampuan Membaca Siswa Pada Mata Pelajaran Bahasa Indonesia Kelas IV. Juran Kajian Pendidikan Dasar (3)1 429-442. Diperoleh dari https://journal.unismuh.ac.id/index.php/jkpd/article/view/1172

Nugrahaningtyas, M. (2021). Peningkatan Hasil Belajar Bahasa Indonesia Materi Pantun melalui Media Power Point Bernarasi pada Siswa Kelas V Semester 1 SDN Cangkol 2 Tahun Pelajaran 2020/2021. Educatif (3)2 1-14. Diperoleh dari http://pub.mykreatif.com/index.php/educatif/article/view/43/36

Sugiyono. (2015). Metode Penelitian Kuantitatif, Kualitatif, dan R\&D. Bandung: Alfabeta.

Susanto, A. (2016). Teori Belajar \& Pembelajaran di Sekolah Dasar. Jakarta: Prenadamedia Group. 